\title{
Oral Habits: Prevalence and Effects on Occlusion Among 7 to 13 Years Old School Children in Aseer, Saudi Arabia
}

\author{
M. Zakirulla1 ${ }^{\circledR}$, Ali Dhafer Alshehri1 ${ }^{\circledR}$, Abdulaziz H. Hudaybi ${ }^{1}$, Sahar N. Fageeh ${ }^{1}$, Abeer A.

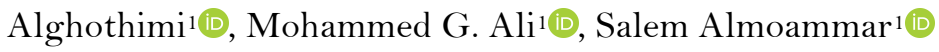

${ }^{1}$ Department of Pediatric Dentistry and Orthodontic Sciences, College of Dentistry King Khalid University, Abha, Kingdom of Saudi Arabia.

Author to whom correspondence should be addressed: Dr. M. Zakirulla, Assistant Professor, Department of Pediatric Dentistry \& Orthodontic Sciences, Division of Pedodontics, College of Dentistry, King Khalid University, Abha, Aseer region, Kingdom of Saudi Arabia. P.O. BOX 3263, Zip Pin - 61471. Phone: +9665305 18766. E-mail: drzak786@gmail.com.

Academic Editors: Alessandro Leite Cavalcanti and Wilton Wilney Nascimento Padilha

Received: 04 February 2020 / Accepted: 11 May 2020 / Published: 30 May 2020

How to cite this article: Zakirulla M, Alshehri AD, Hudaybi AH, Fageeh SN, Alghothimi AA, Ali MG, et al. Oral habits:
prevalence and effects on occlusion among 7 to 13 years old school children in Aseer, Saudi Arabia. Pesqui Bras
Odontopediatria Clín Integr. 2020; 20:e0005. https://doi.org/10.1590/pboci.2020.094

\begin{abstract}
Objective: To evaluate the prevalence of deleterious oral habits and its effect on occlusion in school going children from 7 to 13 years old, in Aseer region of Saudi Arabia. Material and Methods: A cross-sectional study was conducted by clinical examination for the total sample of 750 , who were attending private/ government schools in Aseer region school. Students were selected by stratified cluster random sampling. Clinical findings of each oral habits, including assessment of malocclusion, were examined involving the following parameters, i.e., crowding, spacing, open bite, crossbite and deep bite. Logistic regression analysis was conducted. Results: Boys had $26.2 \%$ of crowded teeth, while $16.3 \%$ of girls were found to have crowded teeth; the difference was found to be significant $(\mathrm{p}=0.002)$. Spacing was present in $26.4 \%$ of boys and $16.7 \%$ girls; a significant difference was found between the two $(\mathrm{p}=0.002)$. Sleep bruxism was observed more among male subjects than females with a statistically significant difference in detrimental habits $(\mathrm{p}<0.001)$. Those subjects having tongue thrusting are 1.264 times at more risk of having crowded teeth than those with no tongue thrusting. Conclusion: There was a high prevalence of malocclusion associated with harmful oral habits in children. This highlighted the need to implement programs of oral care and health education for preventive orthodontic treatment at an early age.
\end{abstract}

Keywords: Epidemiology; Fingersucking; Mouth Breathing; Sleep Bruxism; Malocclusion; Children. 


\section{Introduction}

The prevalence of oral habits varied among different societies [1,2]. The extent of these effects varies from case to case, depending on a wide range of variables including the actual habit employed, the duration and intensity of the habit, and the inherent dental and skeletal relationship. Some of the negative sequelae associated with prolonged habits like thumb sucking and tongue thrusting include a higher incidence of anterior open bite, maxillary incisor protrusion, class II canine relationship, distal step molar relationship, posterior cross bites, and lip incompetence [3]. Oral habits are important environmental factors that may lead to dental malocclusion [4,5]. The severity of the malocclusion correlated with oral habits depends on the frequency, duration and intensity of the habit [6]. These habits disrupt muscular balance and bone growth, producing changes in the dental arch and occlusal characteristics. The cost, time and resource implications of the treatment of malocclusions caused by prolonged oral habits are significant for many patients, especially those who are unable to afford such care [7].

Oral habits should be diagnosed in the initial stages if not will progress to very complex problems challenging to correct it at a later stage. Sometimes, in severe cases, even it requires orthognathic surgery to correct the jaw position altered with such habits [8]. So, these habits require proper attention to provide essential care to child patients. Hence, the study will be conducted to establish the prevalence of deleterious oral habits among children.

\section{Material and Methods}

Study Design and Sample

A cross-sectional study includes a sample of total 750 school children ranged in age from 7 to 13 years old, which were attending private / government schools in Aseer region, Saudi Arabia.

From the literature survey, the expected prevalence is $85.78 \%$, so for precision $2.5 \%$, the estimated sample size is 750 . To calculate, we have used the following formula $[9]: n=\frac{z^{2} p(1-p)}{d^{2}}$; where $\mathrm{n}=$ sample size; $\mathrm{Z}=\mathrm{z}$ statistics for given level of confidence $=1.96$ (for $95 \%$ C.I.); $\mathrm{p}=$ expected prevalence $=85.78 \% ; \mathrm{d}=$ Precision $=0.025$ or $2.5 \%$.

A stratified cluster random sampling procedure was followed to get a representative sample of school children in Aseer region. A detailed list of all primary school and secondary schools in the city was obtained through the concerned authority. Nine schools were randomly selected and the required official permission for the study was obtained from respective school authorities.

\section{Training and Calibration}

The investigator was trained in the Department of Pedodontic Dentistry, College of Dentistry, on 10 subjects. Calibration was done on 10 subjects who examined twice using diagnostic criteria for malocclusion and oral habits between the two examinations, and then the results were compared to diagnostic variability. The same children were re-examined again by the examiners after 10 days to eliminate the chance of memory bias. During calibration, Kappa values for intra- and inter-examiner reproducibility were 0.85 and 0.93 , respectively.

\section{Data Collection}

Clinical examination was carried out by examiners by using latex gloves, mouth mirrors and probe using natural light. WHO guidelines were used to detect the presence and the type of parafunctional oral 
habits [10]. Presence or absence of oral habits like tongue thrust, mouth breathing, thumb sucking, lip biting, sleep bruxism, nail-biting and object chewing was recorded. Clinical findings of each oral habits, including assessment of malocclusion, were examined involving the following parameters ie., crowding, spacing, open bite, crossbite and deep bite. Children with oral and dental treatment needs were referred to College of Dentistry, for further counseling and treatment.

As inclusion criteria, all children aged 7-13 years, while the following conditions were established as exclusion criteria: mentally disabled children, children with developmental disabilities and medically compromised children.

\section{Data Analysis}

The data were collected over a period of 3 months. Data entry was done in SPSS version 18 (IBM SPSS Inc., Chicago, IL, US) and statistical analysis was performed. Logistic regression analysis was used.

Ethical Clearance

The study was approved by the Research Committee at the College of Dentistry, King Khalid University (Ref No: SRC/ETH/2017-18/052 \& 047). Voluntary informed consent was obtained from the parents before the examination of the child.

\section{Results}

A total of 750 children participated in the study, of which $53 \%$ were boys, and $47 \%$ were girls. In the present study, the prevalence of oral habits was $15.6 \%$. The frequency distribution of oral habits and malocclusion traits of subjects is shown in Figures 1 and 2, respectively.

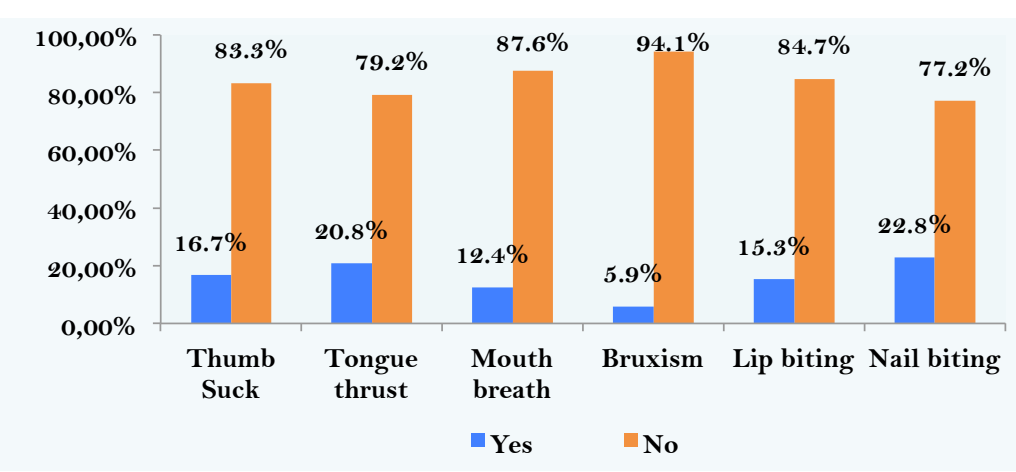

Figure 1. Frequency distribution of oral habits among subjects.

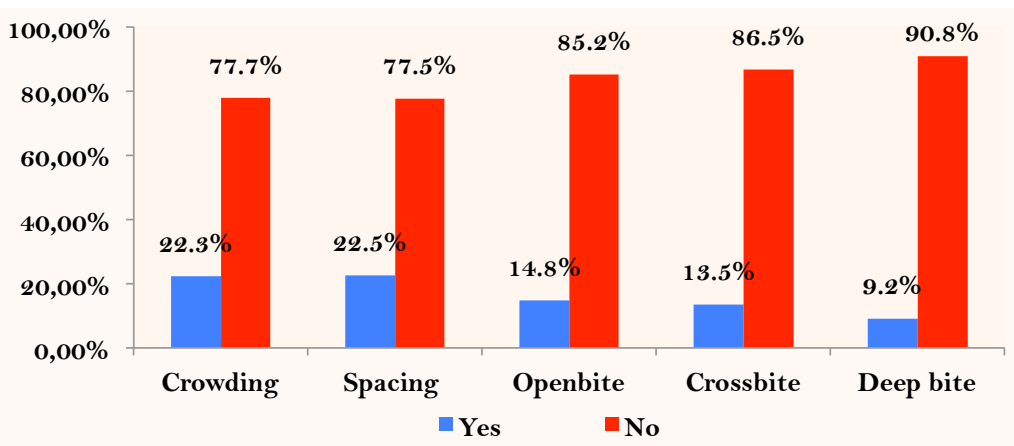

Figure 2. Frequency distribution of malocclusion traits among subjects. 
A non-significant difference between oral habits and malocclusion traits was compared based on different age groups of the subjects (Tables 1 and 2 ). A total of $26.2 \%$ of boys had crowded teeth, while $16.3 \%$ of girls were found to have crowded teeth; the difference was found to be significant $(\mathrm{p}=0.002)$.

Table 1. Frequency distribution of mal-occlusal traits according to different age groups.

\begin{tabular}{|c|c|c|c|c|c|c|c|c|c|c|}
\hline \multirow[b]{2}{*}{ Age (Years) } & \multicolumn{2}{|c|}{ Crowding } & \multicolumn{2}{|c|}{ Spacing } & \multicolumn{2}{|c|}{ Open Bite } & \multicolumn{2}{|c|}{ Crossbite } & \multicolumn{2}{|c|}{ Deep Bite } \\
\hline & $\begin{array}{c}\text { Absent } \\
\%\end{array}$ & $\begin{array}{c}\text { Present } \\
\%\end{array}$ & $\begin{array}{c}\text { Absent } \\
\%\end{array}$ & $\begin{array}{c}\text { Present } \\
\%\end{array}$ & $\begin{array}{c}\text { Absent } \\
\%\end{array}$ & $\begin{array}{c}\text { Present } \\
\%\end{array}$ & $\begin{array}{c}\text { Absent } \\
\%\end{array}$ & $\begin{array}{c}\text { Present } \\
\%\end{array}$ & $\begin{array}{c}\text { Absent } \\
\%\end{array}$ & $\begin{array}{c}\text { Present } \\
\%\end{array}$ \\
\hline $7-9$ & 80.3 & 19.7 & 79.0 & 21.0 & 83.8 & 16.2 & 84.7 & 15.3 & 90.4 & 9.6 \\
\hline $10-11$ & 74.6 & 25.4 & 76.7 & 23.3 & 87.9 & 12.1 & 87.5 & 12.5 & 89.6 & 10.4 \\
\hline $12-13$ & 78.3 & 21.7 & 76.9 & 23.1 & 84.0 & 16.0 & 87.2 & 12.8 & 92.2 & 7.8 \\
\hline p-value & \multicolumn{2}{|c|}{0.312} & \multicolumn{2}{|c|}{0.791} & \multicolumn{2}{|c|}{0.356} & \multicolumn{2}{|c|}{0.723} & \multicolumn{2}{|c|}{0.576} \\
\hline
\end{tabular}

Table 2. Frequency distribution of oral habits according to different age groups.

\begin{tabular}{|c|c|c|c|c|c|c|c|c|c|c|c|c|}
\hline \multirow{2}{*}{$\begin{array}{c}\text { Age } \\
\text { (Years) }\end{array}$} & \multicolumn{2}{|c|}{$\begin{array}{l}\text { Thumb } \\
\text { Sucking }\end{array}$} & \multicolumn{2}{|c|}{$\begin{array}{l}\text { Tongue } \\
\text { Thrusting }\end{array}$} & \multicolumn{2}{|c|}{$\begin{array}{c}\text { Mouth } \\
\text { Breathing }\end{array}$} & \multicolumn{2}{|c|}{ Sleep Bruxism } & \multicolumn{2}{|c|}{ Lip Biting } & \multicolumn{2}{|c|}{ Nail Biting } \\
\hline & $\begin{array}{c}\text { Abs. } \\
\%\end{array}$ & $\begin{array}{c}\text { Pres. } \\
\%\end{array}$ & $\begin{array}{c}\text { Abs. } \\
\%\end{array}$ & $\begin{array}{c}\text { Pres. } \\
\%\end{array}$ & $\begin{array}{c}\text { Abs. } \\
\%\end{array}$ & $\begin{array}{c}\text { Pres. } \\
\%\end{array}$ & $\begin{array}{c}\text { Abs. } \\
\%\end{array}$ & $\begin{array}{c}\text { Pres. } \\
\%\end{array}$ & $\begin{array}{c}\text { Abs. } \\
\%\end{array}$ & $\begin{array}{c}\text { Pres. } \\
\%\end{array}$ & $\begin{array}{c}\text { Abs. } \\
\%\end{array}$ & $\begin{array}{c}\text { Pres. } \\
\%\end{array}$ \\
\hline $7-9$ & 84.3 & 15.7 & 79.5 & 20.5 & 90.4 & 9.6 & 92.6 & 7.4 & 90.4 & 9.6 & 77.3 & 22.7 \\
\hline $10-11$ & 80.4 & 19.6 & 80.4 & 19.6 & 85.0 & 15.0 & 94.2 & 5.8 & 89.6 & 10.4 & 74.2 & 25.8 \\
\hline $12-13$ & 85.1 & 14.9 & 77.9 & 22.1 & 87.5 & 12.5 & 95.4 & 4.6 & 92.2 & 7.8 & 79.7 & 20.3 \\
\hline p-value & \multicolumn{2}{|c|}{0.330} & \multicolumn{2}{|c|}{0.789} & \multicolumn{2}{|c|}{0.208} & \multicolumn{2}{|c|}{0.409} & \multicolumn{2}{|c|}{0.303} & \multicolumn{2}{|c|}{0.322} \\
\hline
\end{tabular}

Abs.: Absent; Pres.: Present.

Spacing was present in $26.4 \%$ of boys and $16.7 \%$ girls; a significant difference was found between the two $(\mathrm{p}=0.002)$ (Table 3). Sleep bruxism was observed more among male subjects than females with a statistically significant difference $(\mathrm{p}<0.001)$ (Table 4$)$.

Table 3. Gender-wise distribution of malocclusion traits among study subjects.

\begin{tabular}{|c|c|c|c|c|c|c|c|c|c|c|}
\hline \multirow[b]{2}{*}{ Gender } & \multicolumn{2}{|c|}{ Crowding } & \multicolumn{2}{|c|}{ Spacing } & \multicolumn{2}{|c|}{ Open Bite } & \multicolumn{2}{|c|}{ Crossbite } & \multicolumn{2}{|c|}{ Deep Bite } \\
\hline & $\begin{array}{c}\text { Absent } \\
\%\end{array}$ & $\begin{array}{c}\text { Present } \\
\%\end{array}$ & $\begin{array}{c}\text { Absent } \\
\%\end{array}$ & $\begin{array}{c}\text { Present } \\
\%\end{array}$ & $\begin{array}{c}\text { Absent } \\
\%\end{array}$ & $\begin{array}{c}\text { Present } \\
\%\end{array}$ & $\begin{array}{c}\text { Absent } \\
\%\end{array}$ & $\begin{array}{c}\text { Present } \\
\%\end{array}$ & $\begin{array}{c}\text { Absent } \\
\%\end{array}$ & $\begin{array}{c}\text { Present } \\
\%\end{array}$ \\
\hline Boys & 73.8 & 26.2 & 73.6 & 26.4 & 87.1 & 12.9 & 86.4 & 13.6 & 89.8 & 10.2 \\
\hline Girls & 83.7 & 16.3 & 83.3 & 16.7 & 82.3 & 17.7 & 86.7 & 13.3 & 92.3 & 7.7 \\
\hline p-value & \multicolumn{2}{|c|}{$0.002^{*}$} & \multicolumn{2}{|c|}{$0.002 *$} & \multicolumn{2}{|c|}{0.075} & \multicolumn{2}{|c|}{1.00} & \multicolumn{2}{|c|}{0.249} \\
\hline
\end{tabular}

\#Fisher exact test; *Highly significant $(\mathrm{p}<0.01)$.

Table 4. Gender-wise distribution of oral habits among study subjects.

\begin{tabular}{|c|c|c|c|c|c|c|c|c|c|c|c|c|}
\hline \multirow[t]{2}{*}{ Gender } & \multicolumn{2}{|c|}{$\begin{array}{c}\text { Thumb } \\
\text { Sucking }\end{array}$} & \multicolumn{2}{|c|}{$\begin{array}{l}\text { Tongue } \\
\text { Thrusting }\end{array}$} & \multicolumn{2}{|c|}{$\begin{array}{c}\text { Mouth } \\
\text { Breathing }\end{array}$} & \multicolumn{2}{|c|}{ Sleep Bruxism } & \multicolumn{2}{|c|}{ Lip Biting } & \multicolumn{2}{|c|}{ Nail Biting } \\
\hline & $\begin{array}{c}\text { Abs. } \\
\%\end{array}$ & $\begin{array}{c}\text { Pres. } \\
\%\end{array}$ & $\begin{array}{c}\text { Abs. } \\
\%\end{array}$ & $\begin{array}{c}\text { Pres. } \\
\%\end{array}$ & $\begin{array}{c}\text { Abs. } \\
\%\end{array}$ & $\begin{array}{c}\text { Pres. } \\
\%\end{array}$ & $\begin{array}{c}\text { Abs. } \\
\%\end{array}$ & $\begin{array}{c}\text { Pres. } \\
\%\end{array}$ & $\begin{array}{c}\text { Abs. } \\
\%\end{array}$ & $\begin{array}{c}\text { Pres. } \\
\%\end{array}$ & $\begin{array}{c}\text { Abs. } \\
\%\end{array}$ & $\begin{array}{c}\text { Pres. } \\
\%\end{array}$ \\
\hline Boys & 84.3 & 15.7 & 79.5 & 20.5 & 90.4 & 9.6 & 92.6 & 7.4 & 90.4 & 9.6 & 77.3 & 22.7 \\
\hline Girls & 80.4 & 19.6 & 80.4 & 19.6 & 85.0 & 15.0 & 94.2 & 5.8 & 89.6 & 10.4 & 74.2 & 25.8 \\
\hline p-value & \multicolumn{2}{|c|}{0.426} & \multicolumn{2}{|c|}{0.783} & \multicolumn{2}{|c|}{0.142} & \multicolumn{2}{|c|}{$<0.001 *$} & \multicolumn{2}{|c|}{0.756} & \multicolumn{2}{|c|}{0.063} \\
\hline
\end{tabular}

\#Fisher exact test; *Highly significant $(\mathrm{p}<0.01)$.

Regression Analysis shows that crowding is significantly related to nail-biting $(\mathrm{p}<0.01)$. The Odd's ratio for thumb sucking is 1.184 , which indicates that children with the habit of thumb sucking are 1.184 times at more risk of developing crowding compared to those with no habit of thumb-sucking. Those subjects having tongue thrusting are 1.264 times at more risk of having crowded teeth than those with no tongue thrusting. 
The risk of having crowding is 1.111 times more in those subjects with the mouth-breathing habit. The Odd's ratio for lip biting and nail-biting was found to be 0.870 and 1.801 , respectively, as far as crowding is concerned (Tables 5 and 6).

Table 5. Regression analysis of different oral habits for crowding (as constant).

\begin{tabular}{|c|c|c|c|c|c|c|c|c|c|}
\hline & \multicolumn{9}{|c|}{ Variables in the Equation } \\
\hline & \multirow[t]{2}{*}{ Oral Habits } & \multirow[t]{2}{*}{ B } & \multirow[t]{2}{*}{ S.E. } & \multirow[t]{2}{*}{ Wald } & \multirow[t]{2}{*}{ df } & \multirow[t]{2}{*}{ p-value } & \multirow[t]{2}{*}{$\operatorname{Exp}(B)$} & \multicolumn{2}{|c|}{ 95.0\% C.I. for $\operatorname{EXP}(B)$} \\
\hline & & & & & & & & Lower & Upper \\
\hline \multirow{7}{*}{$\begin{array}{l}\frac{\sigma}{2} \\
\text { Dे } \\
\text { in }\end{array}$} & Thumb Sucking & 0.169 & 0.240 & 0.498 & 1 & 0.480 & 1.184 & 0.740 & 1.895 \\
\hline & Tongue thrusting & 0.235 & 0.221 & 1.124 & 1 & 0.289 & 1.264 & 0.820 & 1.951 \\
\hline & Mouth breathing & 0.105 & 0.273 & 0.148 & 1 & 0.700 & 1.111 & 0.651 & 1.897 \\
\hline & Sleep Bruxism & 0.560 & 0.340 & 2.701 & 1 & 0.100 & 1.750 & 0.898 & 3.410 \\
\hline & Lip biting & -0.139 & 0.256 & 0.295 & 1 & 0.587 & 0.870 & 0.527 & 1.437 \\
\hline & Nail biting & 0.588 & 0.203 & 8.420 & 1 & $0.004 *$ & 1.801 & 1.210 & 2.679 \\
\hline & Constant & -1.508 & 0.151 & 100.202 & 1 & $0.000 *$ & 0.221 & & \\
\hline
\end{tabular}

arariables entered on step 1: Thumb Suck, Tongue Thrust, Mouth Breath, Sleep Bruxism, Lip Biting, Nail Biting; *Significant (p<0.05).

Table 6. Distribution types of deleterious oral habits and associated with malocclusion.

\begin{tabular}{lccccc}
\hline Types of Oral Habits & Crowding & Spacing & Open bite & Crossbite & \multicolumn{2}{c}{ Deep Bite } \\
& $\mathrm{N}(\%)$ & $\mathrm{N}(\%)$ & $\mathrm{N}(\%)$ & $\mathrm{N}(\%)$ & $\mathrm{N}(\%)$ \\
\hline Thumb Sucking & $0(0.0)$ & $6(8.0)$ & $21(30.0)$ & $15(21.0)$ & $0(0.0)$ \\
Tongue Thrusting & $7(8.0)$ & $12(13.0)$ & $26(29.0)$ & $15(16.0)$ & $3(4.0)$ \\
Mouth Breathing & $4(8.0)$ & $15(30.0)$ & $18(37.0)$ & $8(17.0)$ & $0(0.0)$ \\
Sleep Bruxism & $4(36.0)$ & $1(9.0)$ & $0(0.0)$ & $1(11.0)$ & $3(27.0)$ \\
Lip Biting & $13(18.0)$ & $10(14.0)$ & $2(3.0)$ & $2(3.0)$ & $0(0.0)$ \\
Nail Biting & $35(38.0)$ & $17(19.0)$ & $11(12.0)$ & $23(25.0)$ & $10(11.0)$ \\
\hline
\end{tabular}

\section{Discussion}

Oral habits such as mouth breathing, abnormal swallowing, thumb sucking, lip sucking and nail-biting can have a direct influence on the quality of life and can affect the stomatognathic system of the body. The present study determined the prevalence of deleterious oral habits and the relationship of oral habits with associated malocclusion in a school-going population of 7 to 13 years old children in Aseer, Saudi Arabia. Malocclusion is established close to its full expression in an individual with the eruption of all permanent teeth, thereby young adolescents at the late mixed dentition and early permanent dentition stage provide a much clear prevalence of malocclusion and its associated oral habit. Previous researchers studied the associations between malocclusions and deleterious oral habits in preschool children in Brazil and found a high prevalence of malocclusions in a pediatric population under the age of 5 and a positive association with deleterious oral habits [11].

This study showed that significant relationships existed between deleterious oral habits and malocclusions. In this study, the highest prevalence of deleterious oral habit was for nail biting, which was $24.2 \%$ of the subjects and the lowest prevalence was for sleep bruxism, which was common in only $6.6 \%$ of the subjects. The severity of malocclusion associated with nail biting depends on intensity, duration, and frequency of habit. This is consistent with the findings of the National Oral Health Survey, which reported the highest prevalence of "habit of biting nails, lips or objects like pencil" among all habits at both 12 (32\%) and 15-years age $(21 \%)$ in the two regions of Himachal Pradesh [12]. Previous authors have also reported a high prevalence of pencil biting $(9.8 \%)$ and nail biting (12.7\%), they found a comparatively low prevalence of tongue thrust among Mangalore children in the age range of 3-16 years [13]. In a study based in Tehran, nail biting was the 
most frequent habit with a prevalence of 12.5\% [14]. Consequently, a study conducted in Saudi Arabia reported the prevalence of sleep bruxism was $37.6 \%$ with the most common oral habit [15]. Nail biting is often associated with anxiety or stress, and the trend of higher prevalence of nail biting practices as age increases could be linked to the challenges children face stressful conditions. Further research into possible causes for this common practice in this population is required.

In the present study, sleep bruxism showed a statistically significant sex difference with higher prevalence in boys $(\mathrm{p}<0.001)$. This finding is similar to that previously reported by other researchers, who found that the prevalence rate of sleep bruxism was higher in boys than in girls $[13,16]$. However, a study in Lebanon showed that the prevalence of sleep bruxism in both genders were equal [17]. On the other hand, thumb-sucking was more prevalent in girls than boys, and the difference was statistically not significant $(\mathrm{p}<0.001)$. It has been established that internal worries and lack of deep affections might increase the risk of development of abnormal oral habits [18]. Therefore, maternal deprivation, commonly seen in families with a large number of children, could explain the significant increase of sleep bruxism and thumb-sucking in children who had a higher mean number of siblings. Also, this was consistent with the increase of abnormal oral habits in children suffering from abnormal psychic stress, such as those whose parents were war prisoners [19].

A positive association exists between deleterious oral habits and malocclusions; however, crowding and spacing seen a statistically significant relationship between males and females school children. The habit of mouth breathing was seen among $12.3 \%$ of the study population, and the results were significantly higher when compared to the findings of the study done among 6 to 12-year-old children who found the habit in only $4.3 \%$ of their population [20]. Our findings agree with the observations described by other authors, that tongue thrusting is more common in boys, although in our study it was found to be' more common with females $(26.2 \%)$ as compared' to males $(23.2 \%)$ [13]. The findings of the present study contrast the observations reported in the literature,'that mouth breathing was more common 'in males (7.8\%) than females $(5.3 \%)[21]$.

Anterior open bite associated tongue thrust when the tongue is thrust between upper and lower teeth each time the patient swallows producing open bite some time the patient allows the tongue to rest in open bite space preventing the bite from closing [22]. The anterior open bite mostly saw in children with tongue thrust because the primary factor in developing the open bite is the tongue thrust. Tongue thrusting is an abnormal tongue position with deviation from the normal swallowing pattern, and mouth breathing may be associated with the anterior open bite, abnormal speech and anterior protrusion of the maxillary incisors [23]. It appears that several factors account for the persistence of infantile swallowing patterns and that tongue thrust plays an important role in the aetiology of open bite as well as in the relapse of treated open bite patients [24]. The both tongue-thrust swallow and teeth apart swallow favor development of disto-occlusion, extreme maxillary overjet, and open bite [25]. Previous authors reported a statistically significant relationship between thumb sucking and Class II malocclusion, open bite, and extreme overjet [26].

Posterior crossbite is more seen in patients with thumb sucking and tongue thrust this agree with previous finds [27]. In the present study, the result shows occurrence of bad oral habit higher in female than male and this result agreed with previous findings [28]. Nonnutritive sucking habits are associated with an atypical swallowing pattern, and with tongue thrusting, which may be related to the development of malocclusions such as posterior crossbite [29]. A study conducted to know about the extent to which nonnutritive sucking habits contribute to malocclusion in the mixed dentition showed that anterior open bite and posterior crossbite were associated with habits of 36 months or more [27]. The presence of crossbite in 
this study was low compared to other study findings [30], that reported a $29.05 \%$ crossbite prevalence. Knowing the etiology of malocclusion is essential to the success of orthodontic treatment because a prerequisite for correction is the elimination of causes. Considering the increased interest in diagnosis and treatment of malocclusions, it is crucial to deepen knowledge by studies that examine the prevalence of malocclusion and the cause-effect relationship between sucking habits and malocclusion [31].

An early interception of crossbites should be aimed at to prevent asymmetric growth abnormalities of the mandible and maxilla [32]. This study was limited by being conducted in only one city in Saudi Arabia. A bigger sample, including school children' from all over the country, is recommended' to better determine the prevalence of parafunctional oral habits and its associated malocclusion trait.

The limitation of this study was that there might have been a margin of error and a possible recall bias from the children regarding there oral habits. Another limitation is that female teenager's age 12 to 13 -yearold may have hormonal changes that have not been recorded, which will affect our results and this described as one of the limitations of this study. Further studies in a similar age group in different regions of Saudi Arabia should be advocated because the assessment of 7-to 8-year-old children will help in formulating guidelines for the general population.

\section{Conclusion}

There was a high prevalence of malocclusion associated' with harmful oral habits in children. Mouth breathing, tongue thrusting, and thumb sucking have a significant impact on malocclusion, resulting in a higher frequency of crowding in anterior teeth, open bite, and spacing. This highlighted the need to implement programs of oral care and health education for preventive orthodontic treatment at an early age. Data provided baseline information for planning preventive strategies to reduce the deleterious oral habits among children.

\section{Authors' Contributions}

\begin{tabular}{|c|c|c|}
\hline MZ & (iD) $0000-0003-0886-9985$ & $\begin{array}{l}\text { Conceptualization, Methodology, Investigation, Formal Analysis, Writing - } \\
\text { Original Draft Preparation and Writing - Review and Editing. }\end{array}$ \\
\hline ADA & (iD) $0000-0002-0805-0374$ & $\begin{array}{l}\text { Conceptualization, Investigation, Writing - Original Draft Preparation and } \\
\text { Writing - Review and Editing. }\end{array}$ \\
\hline $\mathrm{AHH}$ & (iD) $0000-0002-8275-6017$ & Writing - Original Draft Preparation and Writing - Review and Editing \\
\hline SNF & (iD) $0000-0002-0242-0135$ & Investigation and Formal Analysis. \\
\hline AAA & (iD) $0000-0001-5588-2731$ & Writing - Original Draft Preparation and Writing - Review and Editing. \\
\hline MGA & (iD) $0000-0002-7811-3465$ & Investigation and Formal Analysis. \\
\hline SA & (iD) $0000-0002-4710-9965$ & Conceptualization and Methodology. \\
\hline
\end{tabular}

\section{Financial Support}

None.

\section{Conflict of Interest}

The authors declare no conflicts of interest.

\section{Acknowledgements}

The authors thank College of Dentistry King Khalid University, Abha, Saudi Arabia for providing the facilities used to carry out this study. 


\section{References}

[1] Farsi NM, Salama FS. Sucking habits in Saudi children: prevalence, contributing factors and effects on the primary dentition. Pediatr Dent 1997; 19(1):28-33.

[2] Garde J, Suryavanshi RK, Jawale BA, Deshmukh V, Dadhe DP, Suryavanshi MK. An epidemiological study to know the prevalence of deleterious oral habits among 6 to 12 year old children. J Int Oral Health 2014; 6(1):39-43.

[3] Bishara SE. Textbook of Orthodontics. Philadelphia: WB Saunders Corp.; 2001.

[4] Larsson E. Dummy- and finger-sucking habits with special attention to their significance for facial growth and occlusion. 4. Effect on facial growth and occlusion. Svensk Tandlakare Tidskr Swed Dent J 1972; 65(12):605-34.

[5] Frazao P, Narvai PC. Socio-environmental factors associated with dental occlusion in adolescents. Am J Orthod Dentofacial Orthop 2006; 129(6):809-16. https://doi.org/10.1016/j.ajodo.2004.10.016

[6] Proffitt WR, Fields Jr HW. Contemporary Orthodontics. St. Louis: Mosby Inc.; 2000. pp. 134-135.

[7] Borrie FR, Elouafkaoui P, Bearn DR. A Scottish cost analysis of interceptive orthodontics for thumb sucking habits. J Orthod 2013; 40(2):145-54. https://doi.org/10.1179/1465313312Y.0000000028

[8] Ferreira HR, Rosa EF, Antunes JL, Duarte DA, Imparato JC, Pannuti CM, et al. Prolonged pacifier use during infancy and smoking initiation in adolescence: evidence from a historical cohort study. Eur Addict Res 2015; 21(1):338. https://doi.org/10.1159/000365351

[9] Al-Hammadi AA, Al-Rabai NA, Togoo RA, Zakirulla M, Alshahrani I, Alshahrani A. Knowledge, attitude, and behavior related to use of miswak (chewing stick): a cross-sectional study from aseer region, Saudi Arabia. Contemp Clin Dent 2018; 9(Suppl 1):S64-S68. https://doi.org/10.4103/ccd.ccd_45_18

[10] World Health Organization. Oral Health Surveys: Basic Methods. Geneva: WHO; 2013.

[11] Cavalcanti AL, Bezerra PKM, Moura C, Bezerra PM, Granville-Gracia AF. Relationship between malocclusion and deleterious oral habits in preschool children in Campina Grande, PB, Brazil. Stom Glas S 2008; 55:154-62. https://doi.org/10.2298/SGSo803154C

[12] Bali RK, Mathur VB, Talwar PP, Chanana HB. National Oral Health Survey and Fluoride Mapping; 2002-2003, Himachal Pradesh, DentalCouncil of India, New Delhi; 2004.

[13] Shetty SR, Munshi AK. Oral habits in children: a prevalence study. J Indian Soc Pedod Prev Dent 1998; 16(2):61-6.

[14] Seraj B, Shahrabi M, Ghadimi S, Ahmadi R, Nikfarjam J, Zayeri F, et al. The prevalence of bruxism and correlated factors in children referred to dental schools of Tehran, based on parent's report. Iran J Pediatr 2010; 20:174-80.

[15] Alouda R, Alshehri M, Alnaghmoosh S, Shafique M, Al-Khudhairy MW. Mother's work status on children's bruxism in a subset of Saudi population. J Int Soc Prevent Communit Dent 2017; 7(Suppl 3):S170-S178. https://doi.org/10.4103/jispcd.JISPCD_384_17

[16] Yassaei S, Rafieian M, Ghafari R. Abnormal oral habits in the children of war veterans. J Clinic Pediatr Dent 2004; 29(3):189-92.

[17] Abou-Atme YS, Melis M, Zawawi KH. Bruxism prevalence in a selective Lebanese population. J Lebanese Dent 2004; 41:31-5.

[18] Jalalian A. The prevalence of thumb-sucking and its effects in children aged of six years in Tehran. [PhD Thesis]. Dentistry Department: Shahid Beheshti University; 1997. 438p.

[19] Abbasi AA, Alkadhi OH, Alhobail SQ, Alyami AS, Alsarhani TM, Almejlad N. Prevalence of parafunctional oral habits in 7 to 15 years old schoolchildren in Saudi Arabia. J Orthod Endod 2017; 3:11. https://doi.org/10.21767/2469-2980.100045

[20] Garde JB, Suryavanshi RK, Jawale BA, Deshmukh V, Dadhe DP, Suryavanshi MK. An epidemiological study to know the prevalence of deleterious oral habits among 6 to 12 year old children. J Int Oral Health 2014; 6(1):39-43.

[21] Om PK, Sindhu S, Karimassery SR, Shukla DK. Oral habits in school going children of Delhi: a prevalence study. J Indian Soc Pedo Prev Dent 2003; $21(3): 120-4$.

[22] Jabur SF and Nisayif DH. The effect of bad oral habits on malocclusions and its relation with age, gender and type of feeding. Mustansiriya Dent J 2007; 4(2):152-6.

[23] Dean JA, McDonald RE, Avery DA. Managing the Developing Occlusion. In: McDonald RE, Avery DA, eds. Dentistry for the Child and Adolescent. 7th ed. St. Louis: CV Mosby and Co.; 2000. pp. 178-2 17.

[24] Grippaudo C, Paolantonio EG, Antonini G, Saulle R, LA Torre G, Deli R. Association between oral habits, mouth breathing and malocclusion. Acta Otorhinolaryngol Ital 2016; 36:386-94. https://doi.org/10.14639/0392-100X-770

[25] Melsen B, Stensgaard K, Pedersen J. Sucking habits and their influence on swallowing pattern and prevalence of malocclusion. Eur J Orthod 1979; 1:271-80.

[26] Singh SP, Utreja A, Chawla HS. Distribution of malocclusion types among thumb suckers seeking orthodontic treatment. J Indian Soc Pedod Prev Dent 2008; 26(7):114-7.

[27] Warren JJ, Bishara SE, Steinbock KL, Yonezu T, Nowak AJ. Effects of oral habits duration on dental characteristics in the primary dentition. J Am Dent Assoc 2001; 132(12):1685-93. https://doi.org/10.142 19/jada.archive.2001.0121

[28] Onyeaso CO. Oral habits among 7-10 years old school children in Ibadan, Nigeria. East Afr Med J 2004; 81(1):16-21.

[29] Vazquez-Nava F, Quezada-Castillo JA, Oviedo-Trevino S, Saldivar-González AH, Sánchez-Nuncio HR, BeltránGuzmán FJ, et al. Association between allergic rhinitis, bottle feeding, nonnutritive sucking habits, and malocclusion in the primary dentition. Arch Dis Child 2006; 91(10):836-40. https://doi.org/10.1136/adc.2005.088484 
[30] Gomes e silva L, Lopes FF, Oliveira AEF, Ribeiro CCC, Leal CB, Lima MVV. Estudio de la prevalencia de mordida cruzada em los pacientes ortodoncios em São Luís - MA. Acta Odontol Venez 2010; 48:34-7. [In Spanish]

[31] Heimer MV, Tornisiello Katz CR, Rosenblatt A. Non-nutritive sucking habits, dental malocclusions, and facial morphology in Brazilian children: a longitudinal study. Eur J Orthod 2008; 30(6):580-5. https://doi.org/10.1093/ejo/cjno35

[32] Meer Z, Sadatullah S, Wahab MA, Mustafa AB, Odusanya SA, Razak PA. Prevalence of malocclusion and its common traits in Saudi males of Aseer region. J Dent Res Rev 2016; 3(3):99-102. https://doi.org/10.4103/2348-2915.194834 